\title{
Chitin, Chitinases and Chitin Derivatives in Biopharmaceutical, Agricultural and Environmental Perspective
}

\author{
Raj Singh ${ }^{1}$ (D), Sushil Kumar Upadhyay ${ }^{1 *}$ (D), Manoj Singh ${ }^{1,2}$ (D), Indu Sharma ${ }^{1}$, Pooja Sharma ${ }^{1}$ (D), Pooja \\ Kamboj ${ }^{1}$, Adesh Saini 1 (D), Reena Voraha 1, Anil Kumar Sharma 1,3 (D), Tarun Kumar Upadhyay 4,* (D), \\ Fahad Khan 5 (D)
}

1 Department of Biotechnology, Maharishi Markandeshwar (Deemed to be University), Mullana-Ambala-133207 (Haryana), India

2 Fmr Young Scientist \& Asst. Professor, National University of Science and Technology (MISiS) Moscow, Russia

3 Fmr Postdoc Fellow \&Sr. Scientist, University of Illinois, Chicago, USA

4 Department of Biotechnology, School of Applied Sciences and Agriculture Research, Suresh Gyan Vihar University, Jaipur, India

5 Department of Biotechnology, Noida Institute of Engineering and Technology, Greater Noida, India

* Correspondence: tarun_bioinfo@yahoo.co.in;

Received: 8.08.2020; Revised: 17.09.2020; Accepted: 21.09.2020; Published: 24.09.2020

\begin{abstract}
Chitin is a major structural polysaccharide after cellulose and exists as the most abundant polymer in nature. Chitin is a nitrogen-containing homopolymer of $\beta-(1,4)$ linked $\mathrm{N}$ Acetylglucosamine. It is a key cell wall component of fungi, also found in a wide range of organisms, including viruses, plants, animals, insect exoskeletons, and crustacean shells. This review focused on the recent developments of applications of chitin, chitinases, and chitin derivatives in biomedicinal, agricultural and environmental perspectives for sustainable development. Chitinases are hydrolytic enzymes responsible for the degradation of chitin and are used in biocontrol against various fungal pathogens and insects to reduce the uses of synthetic fungicides and insecticides. These can serve as sustainable and eco-friendly alternatives to pesticides. Chitinases producing microorganisms are a potential alternative to these chemicals which are present in the soil as a part of the ecosystem. Chitin derivatives and chitinases have significant pharmacological values and are effective as an antiinflammatory drug, ulcerative colitis, anticancer and gastrointestinal disorders. The significant medical roles of chitinases have also been observed to amplifying the functioning of antifungal drugs during the treatment of fungal diseases. These enzymes can be used for strengthened the human immune system and also employed antifungal creams and lotions as rightly expected. Chitin derivatives have a number of applications in the making of artificial medical articles, including contact lenses, artificial skin, and surgical stitches. These derivatives have been extensively used in making artificial medical products because of its non-toxic, non-allergic, biocompatible, and biodegradable properties. Chitin and its derivatives used for environmental applications comprise bioremediation of organic and inorganic contaminants from soil and water along with biological conversions of chitinous waste to the singlecell proteins, bioethanol, and biofertilizers as well.
\end{abstract}

Keywords: Chitin; Chitinases; Biomedicine; Biocontrol; Bioremediation; Biofertilizer.

(C) 2020 by the authors. This article is an open-access article distributed under the terms and conditions of the Creative Commons Attribution (CC BY) license (https://creativecommons.org/licenses/by/4.0/).

\section{Introduction}

Chitin is an insoluble amino polysaccharide composed of $\beta-1,4-\mathrm{N}$-acetylglucosamine [1]. It is a chief component of the cell wall among higher fungi belong to Chytridiomycetes, 
Ascomycetes, Basidiomycetes, and Deuteromycetes, the exoskeleton of insects and crustacean external shells. Chitin present in a variety of microorganisms, which includes bacteria and fungi [2]. Bacteria are known for producing many secondary metabolites, which may have great potentials in the fields which are related to mankind [3]. Chitin was discovered by Henri Brancott in 1811, a professor of Natural History. It was first discovered by an English scientist, A. Hachette, who described it as a material that is predominantly resistant to the usual chemicals. In 1843 Lassaigne found that chitin contains nitrogen. Henri Brancott named it 'fungine'. It was found by the Oder in insects and plants in 1823, called it chitins. Chitin is found richly in nature and lies next to cellulose [4].

Chitinases are chemically hydrolytic enzymes liable to the degradation of chitin, a high molecular weight linear polymer of $\mathrm{N}$-acetyl-D-glucosamine units. Chitinases can be found in a wide range of organisms' viz. plants, bacteria, fungi, and invertebrates [5-9]. Chitinase can be dividing into two types: i. endochitinases, and ii. exochitinases. The endochitinases can cleave chitin at internal sites to generate multimers of GlcNAc; however, the exochitinases facilitates the swift hydrolysis of chitin to produce GlcNAc, chitobiose, or chitotriose [10]. Chitinase-synthesizing bacteria are isolated from natural sources such as soil and other natural sources such as aquatic habitats [11-12]. Many bacteria, including Serratia marcescens Aeromonas sp., Pseudomonas aeruginosa, Enterobacter, and S. griseus, can synthesize several different chitinases [13-14]. Chitinases are the major factor of quite a lot of bacterial species, including Aeromonas, Serratia, Vibrio, Streptomyces, Bacillus, Aeromonas hydrophila, and A. punctata $[10,15]$. Chitinolytic bacteria can also be isolated from the rhizosphere of a wide variety of plants $[3,16]$. The fungal cell wall has a complex cross-linked structure composed of chitin, and the bacteria producing chitinase enzymes play an important role in lysing these cells by degrading the chitin [17].

In fungal chitinases play an important role in nutrition, morphogenesis, and biological roles like lysis of the cell wall, which helps in the screening of cells after division, hyphal autolysis, nutritional chuck, and morphogenetic formation, which helps in sporulation, spore germination, hyphal escalation and antagonistic dealings against additional microorganisms [17]. Chitinases can play a major role in many areas such as the production of single-cell protein, growth factors, mosquito control, ethanol and fertilizer, a biocontrol agent of fungal pathogens, isolation of fungal protoplasts, and antifungal drugs [18-25]. Thus, the need for microbial chitinase production has increased, and it fulfills two purposes: (i) trim down the environmental hazards and (ii) augmented production of industrially imperative value-added products [26]. The study was proposed to know the potential of different organisms for the production of chitinases and their sustainable role in human health, biocontrol, agriculture, and environment, etc.

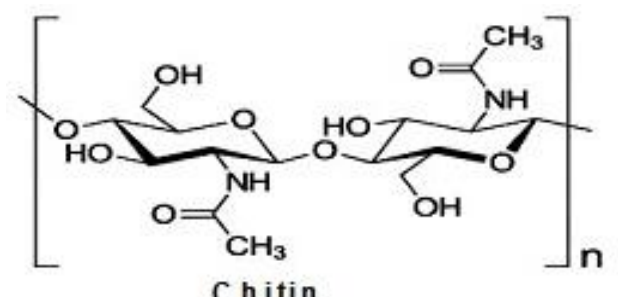

Chitin

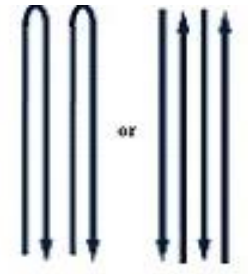

a-C hitin

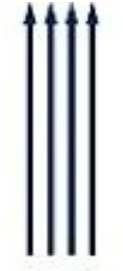

$\beta-C h$ itin

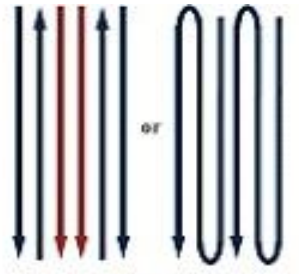

$\mathrm{v}-\mathrm{C}$ hitin

Figure 1. Molecular structure and different polymeric configurations of chitin. 


\section{Chitin: structure, properties, sources, and extraction}

\subsection{Structure of chitin.}

In nature, chitin can be found in three different polymeric forms: $\alpha, \beta$, and $\gamma$ [27]. The $\alpha$ form is universally found and is generally collected from crab and shrimp shells and has an antiparallel arrangement, and $\beta$ form is mainly acquired from mollusks and has a parallel arrangement in contrast to the $\alpha$ form. The $\alpha$ and $\beta$ forms of chitin are economic in nature, and both differ in the packaging and polarities of straight chains in the chitin sheets. While in the case of $\gamma$, chitin has two parallel strands and two antiparallel strands. The $\beta$ form is not convertible into alpha form, but $\gamma$ chitin is convertible into $\alpha$ chitin by treating it with lithium thiocyanate (Fig. 1).

\subsection{Properties of chitin.}

Chitin is not soluble in water due to the strong intermolecular hydrogen bonding [28]. But there are certain chitin-based derivatives which are soluble in water, such as chitosan or carboxymethyl, which can be obtained from chitin, and the most important advantages of these compounds in which they are really flexible so that they can be molded into various forms like fibers, hydrogels, beads, sponges, and membranes. Chitin is crystalline in nature, and the tensile strength is much higher than most of the manufactured materials [29]. The extensive hydrogen bonding within the chains of chitin is the reason for the high tensile strength of chitin. A significant amount of chitin is present in almost all fungi, which give the evidence that the polymer is widely distributed in the kingdom Fungi and phylum Arthropoda and Mollusca of kingdom Animalia [9, 30].

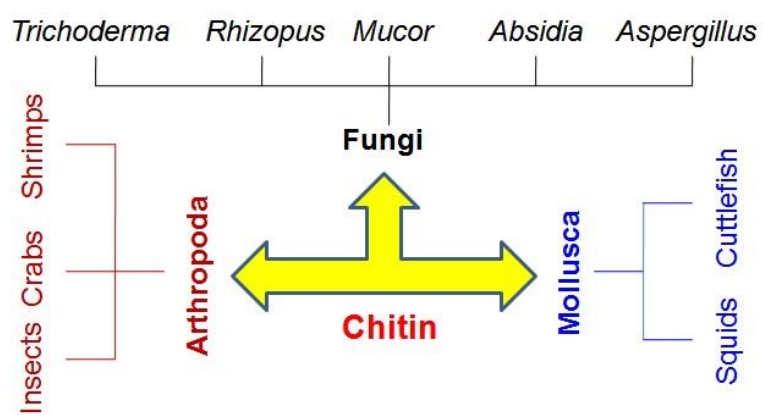

Figure 2. Potential natural sources of chitin.

\subsection{Sources of chitin.}

There are large numbers of complex intracellular processes are involved in the formation of chitin comprising the biotransformation of trouble-free metabolites and formation of the polymer, chitin [30]. The accumulation of catalytic units in the cell membrane allows polymerized GlcNAc molecules to be a force out into the extracellular environment. The raw materials which are widely available for the manufacturing of chitin are insects, crab shells, shrimps and lobsters, and fungi (Fig. 2) [31]. The main potential animal sources for chitin production and its harvestings are insects (e.g., Beetles, Moths Bombyx mori, Honey bees Apis sp., Mosquitoes Aedes aegypti, etc.); crabs (e.g., Golden king crab Lithodes aequispinus, Snow crab Chionoecetes opilio, Tanner crab C. bairdi, Korean hair crab Erimacrus isenbeckii, Blue king crab Paralithodes platypus, Red king crab P. camtchaticus, etc.); shrimps (e.g., Penaeus 
carinatus, P. monodon, Litopenaeus vannamei, Parapenaeopsis stylifera, etc.); lobsters (e.g., Homarus americanus, Jasus lalandii, etc.); mollusks (e.g., Cuttlefish Sepia offcinalis, Squid Loligo vulgaris, etc.); fungi (e.g., Absidia blakesleeana, A. coerulea, A. glauca, Aspergillus niger, Gongronella butleri, Lentinus edodes, Mucor rouxii, Phycomyces blakesleeanus, Rhizopus oryzae, Trichoderma reesei, etc.) [32-53].

\subsection{Extraction of chitin.}

For the extraction, harsh treatments are required because chitin is found associated with other constituents. In the present chitin, production is hugely dependent on canning industries as they produce crab and shrimp shells as their waste products. Chitin is now commercially manufactured in India, Japan, Poland, Norway, and Australia. In India, the Central Institute of Fisheries Technology, Kerala, was the first to start research on chitin and reported that the dry waste of prawn had 23\% chitin; however, dry Squilla had 15\% chitin content [54]. The process of conversion of chitinous waste to commercial products is very useful in view of their great economic value and versatile biological and chemical applications, chiefly in medical and pharmaceutical areas (Fig. 3).

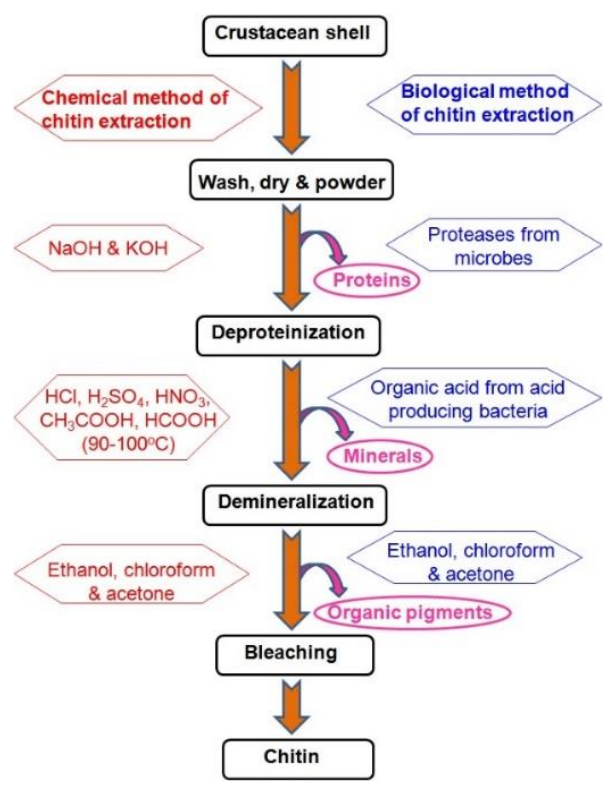

Figure 3. The extraction of chitin by chemical and biological methods.

\section{Chitinase: structure, properties, and types}

Chitinases are various groups of enzymes that show variations in the structure, substrate specificity, and acting mechanism [32]. The size range of these enzymes lies between $20 \mathrm{kDa}$ to about $90 \mathrm{kDa}[55]$.
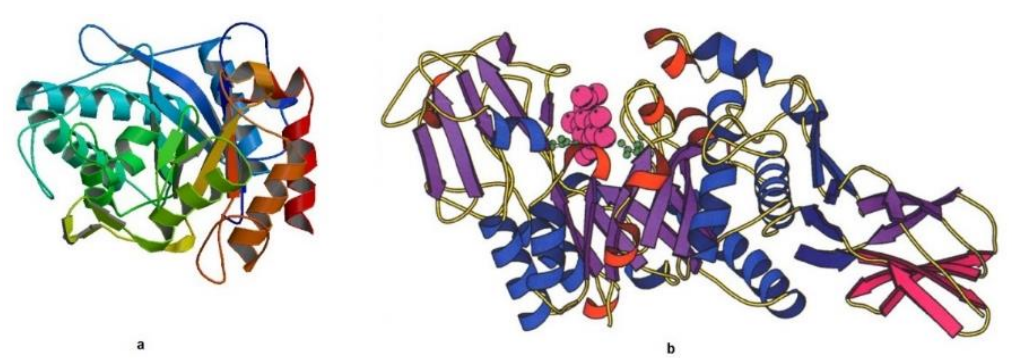

Figure 4. Structure of wild type chitinase (a) and bacterial chitinase-A, ChiA (b). 


\subsection{Structure of chitinases.}

The structure of chitinase is modular, having one catalytic and single or many noncatalytic domains that could or couldn't play a task during substrate binding (Fig. 4). The bacterial chitinases showed no concern to the resemblance between the catalytic and chitinbinding domains in pairwise comparative accounts that implies to the fact that chitin-binding domains in bacterial chitinases are conserved evolutionarily (Fig. 4) [56]. As the chitinases of different families have no amino acid sequence similarity and have different three-dimensional structures, it is likely that they have evolved from different ancestors [57]. Family 18 contains repeats of amino acids, and their enzyme core consists of eight strands of parallel $\beta$ sheets, which form a barrel, and alpha helices are present below this barrel, which is present in the form of a ring towards the outside (Fig. 5) [58]. The polydomain structure of family 19 included catalytic domains, a cysteine affluent chitin-binding domain, and a serine/ threonine rich glycosylated domain, which have been discovered as the structural characteristics of chitinases in various organisms (Fig. 5) [59]. The bacterial and fungal chitinases show a very close association in terms of their structure, strongly suggesting that the catalytic domains in all of these microorganisms are greatly similar.

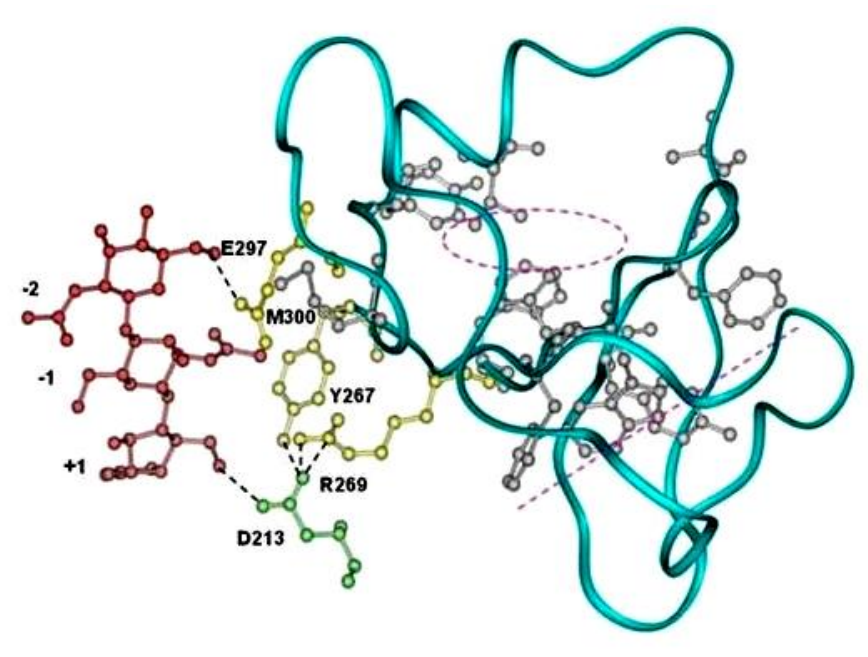

a

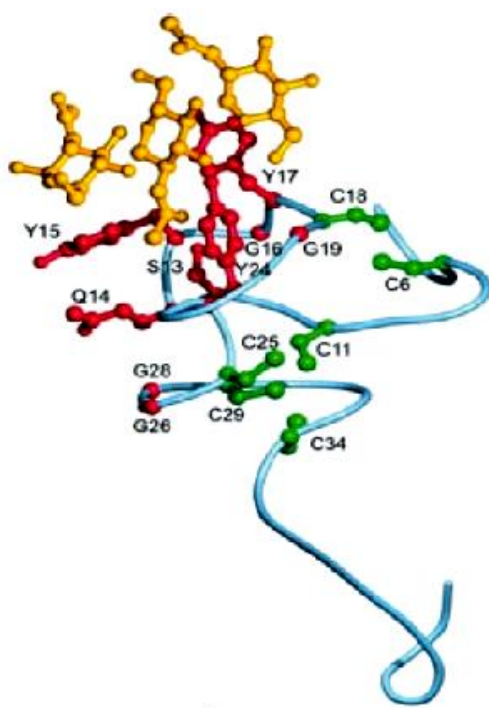

b

Figure 5. Structure of family 18 (a) and family 19 (b) chitinase.

\subsection{Properties of chitinases.}

The study substrate specificity is important for chitinases because it divulges the relationship between substrate specificity and physiological roles. Enzyme nomenclature has listed chitinolytic enzymes as chitinases and $\mathrm{N}$-acetyl- $\beta$-glucosaminidase. The chitinase breaks chitin polymers, and the $\mathrm{N}$-acetyl- $\beta$-glucosaminidase degrades terminal $\mathrm{N}$-acetyl- $\beta$ glucosamine residues lying on the non-reducing end from chitobiose and higher analogs. Chitinases are hydrolytic enzymes that are capable of breakdown the $\beta$ - $(1,4)$-glycoside bond of chitin, a main structural component in insect exoskeletons and fungal cell walls. Chitinases are created by higher plants, which utilize the catalysts to safeguard themselves against pathogenic assaults by corrupting chitin in the cell wall of microbes [6]. The chitin is degraded into chito-oligomers by chitinases, which serve a broad range of applications. 


\subsection{Types of chitinases.}

Chitinases are broadly divided into two classes (endochitinases and exochitinases) on the basis of its synthesis and nomenclature [10]. The endochitinases split chitin and chitin microfibrils at random internal sites to produce soluble, low molecular mass products, e.g., chitotetraose, chitotriose, and diacetyl-chitobiose (Fig. 6). The exochitinases can catalyze the hydrolysis of chitin progressively to produce N-acetylglucosamine, GalNAc (Fig. 7). Exochitinases have been divided into two categories: chitobiosidases, and $\beta-(1,4)-\mathrm{N}-$ acetylglucosaminidases [8].

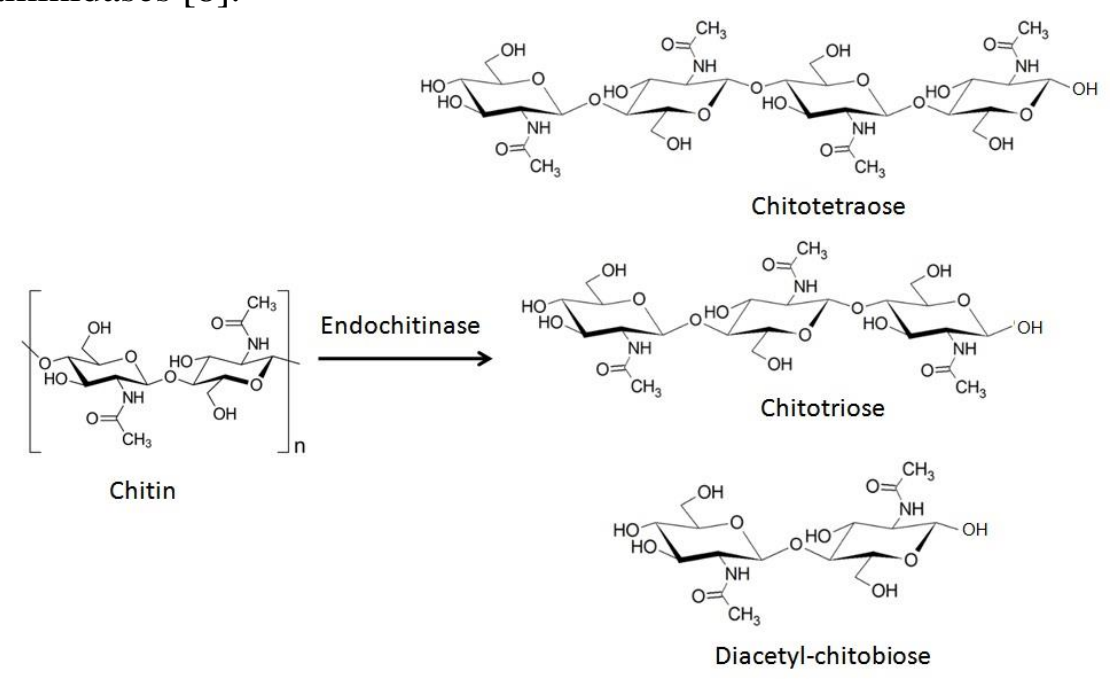

Figure 6. Chemical reaction for hydrolysis of chitin by endochitiases.

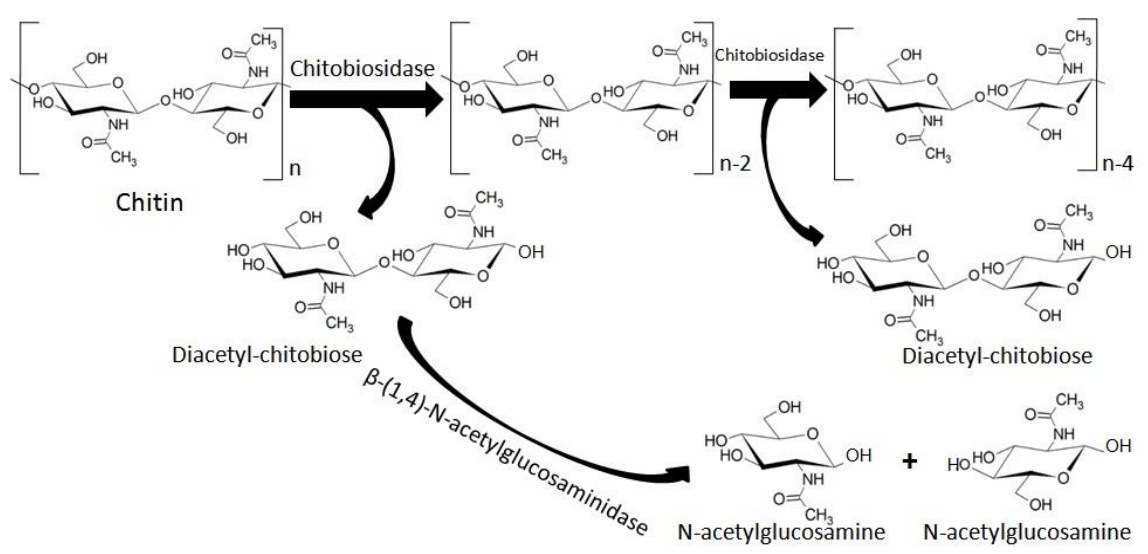

Figure 7. Chemical reaction for chitin hydrolysis by exochitiases.

The chitobiosidases act on a non-reducing terminal of chitin, and release diacetylchitobiose dimer from the parent chitin chain. However, $\beta-(1,4)-\mathrm{N}-$ acetylglucosaminidases split the polymeric products (e.g., di-acetylchitobiose, chitotriose, and chitotetraose) into monomers of $\mathrm{N}$-acetylglucosamine [30]. The gene sequences of the chitinases came to be known; these were further divided into six classes based on their sequences [60-62]. Class-I chitinases had a cysteine-rich N-terminal, leucine- or valine-rich signal peptide, and vacuolar localization. These chitinases are further subdivided on the basis of their acidic or basic nature into class-Ia and class-Ib, respectively. This group contains only plant chitinases, and most of these are endochitinases. Class-II chitinases had a similar sequence to class-I chitinases. These are found in plants, fungi, bacteria, and most of these are exochitinases. Class-III chitinases have no similar sequences to class-I or class-II. Class-IV chitinases had similar characteristics as class-I chitinases, but these chitinases were really 
smaller in size than class-I chitinases. Class-V and class-VI chitinases are not clearly characterized so far.

\subsection{Natural sources of chitinases.}

The chitinases are derived from various natural resources, including bacteria, fungi, plants, and animals in variable quantities. Bacteria are major sources of chitinase and produce mainly to hydrolyze chitin and use it as a source of energy. Chitinase-synthesizing bacteria are isolated from natural sources such as soil and other natural sources such as aquatic habitats [11-12, 62]. Some chitinases produced from of chitinolytic bacteria, such as Serratia marcescens, Enterobacter sp. Aeromonas hydrophila, A. punctata, Serratia, Vibrio, Streptomyces, and Bacillus [10, 14, 15, 62]. Chitinolytic bacteria can also be isolated from the rhizosphere of a wide variety of plants $[3,16]$. The fungal cell wall has a complex cross-linked structure composed of chitin, and the bacteria producing chitinase enzymes play an important role in lysing these cells by degrading the chitin [17].

The production of chitinase in the case of filamentous fungi can be observed throughout its life cycle [63]. In fungi, this enzyme plays an important role in releasing the spores and also in the hyphal branching [5]. In yeast, chitinase has a role in cell separation [64]. Chitinase also plays an essential role in nutrition by helping in the utilization of chitin for its carbon and nitrogen requirements [65]. In a few cases, it also plays a role in pathogenicity [66]. Many earlier scientists have been reported the purification and characterization of $3 \mathrm{~N}$ acetylglucosaminidase (GlcNAcases) from various isolates of Trichoderma spp. [67-69]. Trichoderma spp. have given the significant contemplation as biocontrol agents of soil-borne fungal pathogens. The chitinases and $\beta-1,3$-glucanases are isolated, purified, and characterized by Talaromyces flavus and Trichoderma spp. and their role in mycoparasitism against soilborne fungi, i.e., Sclerotium rolfsii, Rhizoctonia solani, and Fusarium sp. has also been reported [70-72].

The plant chitinases have been reported in both monocotyledonous and dicotyledonous species and have been found in different types of structures like embryos and cotyledons, seeds, leaves, and stems, roots and flowers, and protoplasts [7, 73-75]. Chitinases have also been reported in crops (e.g., barley, rice, onion, wheat, etc.) and non-crop species like Arabidopsis, poplar, and rubber [8]. Their production is influenced by a variety of factors, such as infection, stress conditions, and phytohormones [76]. The plant chitinases are delivered as proteins in plant self-preservation because of the assault of phytopathogens [77]. The chitinases take part in vital physiological processes of plants, like embryogenesis and ethylene synthesis [56]. Garg and Gupta isolate and purify the chitinase from moth beans attacked by the fungus Macrophomina Phaseolina strain 2165 [78].

\subsection{Production of chitinases.}

Microbial chitinases have been fashioned by liquid batch fermentation, incessant fermentation, and fed-batch fermentation (Fig. 8) [1]. Additionally, solid-state fermentation and biphasic cell systems have also been used for the mass scale production of chitinases. The chitinases produced by microbes are usually inducible categories. Components of media, carbon sources, nitrogen sources, and agricultural residues viz., rice bran, wheat bran, etc. also affect extracellular chitinase production [13, 79]. An alluring impact of glucose on chitinase creation was accounted for when glucose was utilized with chitin in the creation medium [79]. 
On the other hand, Miyashita et al. reported a suppressing effect of glucose on chitinase production [80]. The temperature, $\mathrm{pH}$, and aeration, also influence chitinase production. Production of chitinase from Bacillus sp. BG-1, also increases when the growth medium is added with amino acids such as tryptophan, tyrosine, glutamine, and arginine (0.1 $\mathrm{mM})$ [79]. The extracellular chitinase production by Serratia marcescens in an aqueous two-phase system (ATP) of PEG and dextran was reported by Chen and Lee [81].

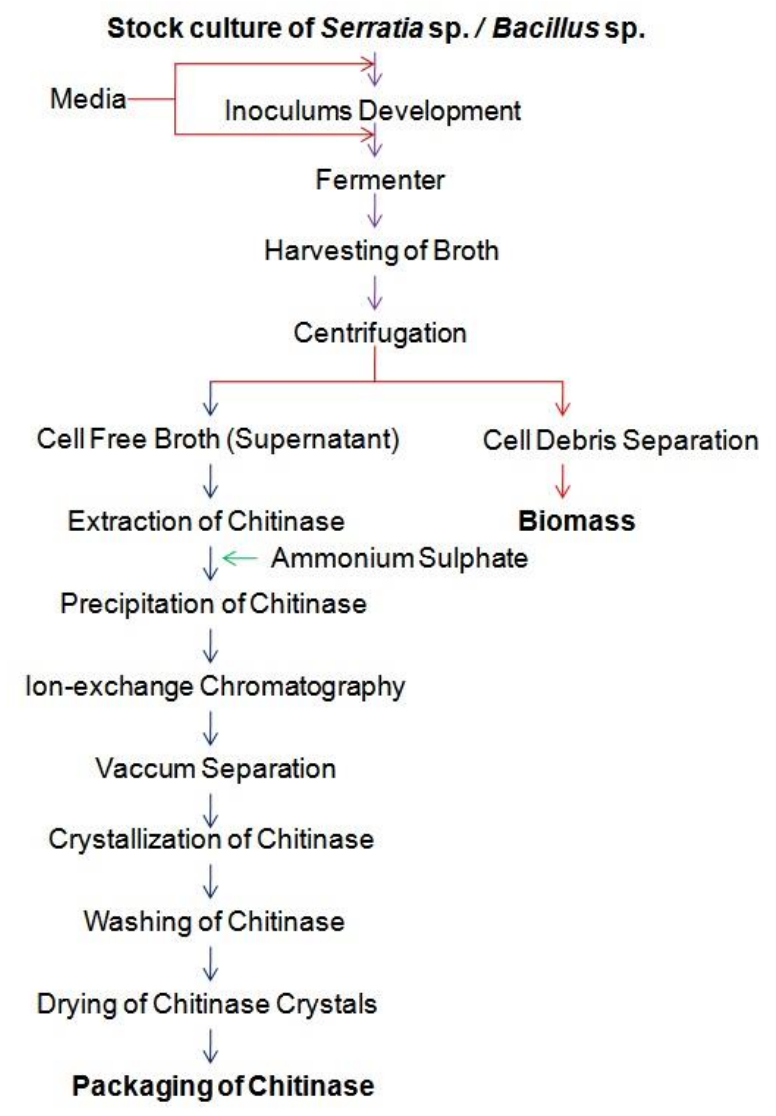

Figure 8. Flow chart showing batch fermentation, production, purification, and packaging of chitinases.

\subsection{Application of chitinases.}

Chitinases can play a major role in many areas such as the production of single-cell protein, growth factors, mosquito control, bioethanol and biofertilizers, a biocontrol agent of fungal pathogens, isolation of fungal protoplasts, and antifungal drugs (Fig. 9) [1, 18-25].

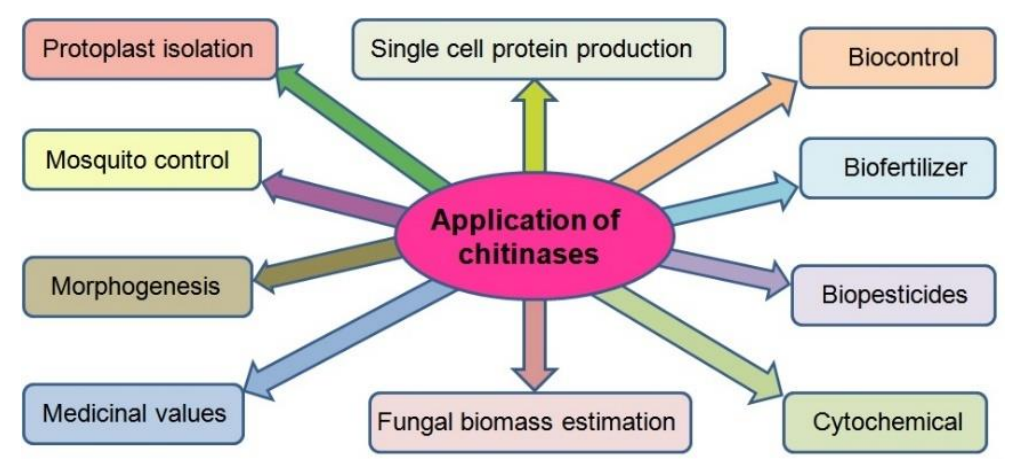

Figure 9. Potential diversification in applications of chitinases.

Thus, the need for microbial chitinase production has increased and solved two purposes: (i) shrink the environmental hazards and (ii) augments manufacture of industrially 
important value-added products [26]. Chitinases are useful for the production of ophthalmic products by the use of chitinases and micro biocides [82]. An important medical use of chitinases has also been observed in amplifying the functioning of antifungal drugs in the treatment of fungal diseases [21]. Due to their applications, their use in antifungal creams and lotions is rightly expected. Several pieces of evidence have explained the importance of chitinases in the defensive immune system of mammals [22]. The presence of bacterial chitinases in humans can play an important role as a component of defense mechanisms against fungal attack [83].

\section{Chitin derivatives and its applications}

GlcNAc (a polymer of chitin) itself acts as an anti-inflammatory drug. It is synthesized in the human body from glucose, and after being synthesized, it is then incorporated into glycoprotein and glycosaminoglycans. The GlcNAc, which is administered in the human body, has been found to be effective in the treatment of ulcerative colitis, gastrointestinal disorders, and inflammation [84]. The uses of chitin might be limited because of its helpless dissolvability, low porosity, and surface zone [85]. Henceforth to conquer the impediments and control the properties of chitin, different noteworthy subsidiaries are created (Table 1). Chitosan is one of the most significant subordinates of chitin as far as appropriateness [86]. Chitin derivatives have a number of applications in the making of artificial medical articles such as contact lenses, artificial skin, and surgical stitches. These derivatives have been extensively used in making artificial medical products because these chitin derivatives have been found to be non-toxic, non-allergic, biocompatible, and biodegradable [87]. Rameshthangam et al. discuss the different biomedical applications of chitin and its derivatives (Fig. 10) [30].

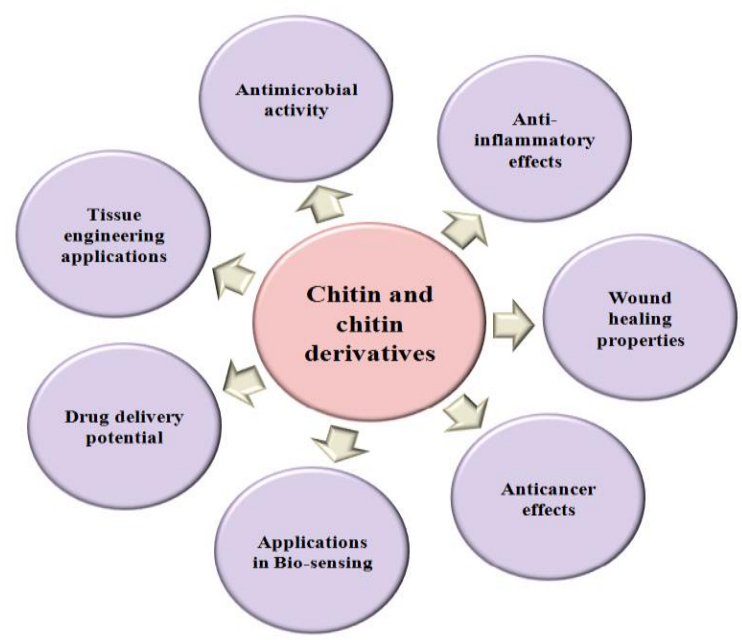

Figure 10. The biomedical applications of chitin and its derivatives.

\subsection{Application in nanomedicine and biomedical engineering.}

Chitosan is one of the most extravagant biopolymers got from characteristic chitin that normally exists in the exoskeletons of arthropods, shellfish shells, creepy crawlies, and parasitic cell dividers [88]. Chitosan is a natural and cationic polysaccharide, has been considered as a promising nanomaterial with broad clinical applications [89-90]. It has remarkable properties, for example, nontoxicity, biocompatibility, biodegradability, bioactivity, and mucoadhesion [91-92]. It very well may be corrupted by interior proteins, for example, lysozymes and chitosanases, to procure oligosaccharides and monosaccharides, 
which are in this manner consumed by the body [93]. Be that as it may, different methodologies for adjusting chitin and chitosan have been created to address these issues [94-95]. Free amino and hydroxyl bunches have been used to create a wide scope of subsidiaries with improved solvency dependent on its high proclivity with useful proteins and the ability to self-collect [96-97]. It tends to be handily prepared in differing structures, for example, films, strings, tablets, layers, and microparticles/ nanoparticles, permitting the plan of an assortment of clinical and pharmacological gadgets versatile to end purposes. Specifically, in medication, chitosan might be valuable in swathes to decrease draining, and as an antibacterial operator can likewise be utilized to help convey drugs through the skin (Fig. 11). It is additionally utilized in the improvement of chitosan medicate control discharging frameworks, including chitosan wipes, chitosan film, chitosan dabs, chitosan microbeads (microspheres), and chitosan nanoparticles. In other words, nano-magnetic is the center and chitosan polymer covering the magnetic centers. The procedure is called a coating. These magnetic nanoparticles can be utilized as incredible transporters for chemical immobilization, and chitosan nanoparticles have an antitumor job through improving the " body's safe capacity or immune system [98]. In spite of the notable points of interest of exploiting chitosan in these fields, extra work should be done to streamline" chitosan's details and upgrade its physicochemical properties for various employments.

Table 1. Biomedical and industrial application of various chitin derivatives.

\begin{tabular}{|c|c|c|c|c|}
\hline S.No. & Chitin derivatives & Process of synthesis & Applications & References \\
\hline 1. & Chitosan & Deacetylation & $\begin{array}{l}\text { Anticancer, antibacterial agent, } \\
\text { enzyme immobilization, }\end{array}$ & $\begin{array}{l}{[85-86,99-} \\
100]\end{array}$ \\
\hline 2. & Alkyl chitin & Deacetylation of chitosan & Antimicrobial agents & [101] \\
\hline 3. & $\mathrm{~N}$ and $\mathrm{O}$ sulfated chitin & Sulfation & Anticoagulant agent, heparin & [102] \\
\hline 4. & Dibutyryl chitin & $\begin{array}{l}\text { Reaction of the chitin with } \\
\text { butyric anhydride }\end{array}$ & $\begin{array}{l}\text { Intermediates for further chemical } \\
\text { modifications }\end{array}$ & [103-104] \\
\hline 5. & $\begin{array}{l}\text { Carboxymethyl chitin } \\
(\mathrm{CMCH})\end{array}$ & Carboxymethylation & Excipients for oral drug delivery & [105-106] \\
\hline 6. & $\begin{array}{l}\text { Chito-oligosaccharides } \\
\text { (COS) }\end{array}$ & $\begin{array}{l}\text { Acid hydrolysis } \\
\text { and oxidative, reductive } \\
\text { depolymerization }\end{array}$ & Nutraceutical additive & [107-108] \\
\hline 7. & Chitin nanofibers (CNF) & $\begin{array}{l}\text { Loosening of tightly } \\
\text { bonded fibrils bundles by } \\
\text { removal of minerals, } \\
\text { proteins, pigments, and } \\
\text { lipids with the treatment } \\
\text { of } \mathrm{HCl}, \mathrm{NaOH} \text {, and } \\
\text { ethanol }\end{array}$ & $\begin{array}{l}\text { Tissue engineering wound } \\
\text { dressing, cosmetic, skin health, } \\
\text { stem cell, anticancer therapy, drug } \\
\text { delivery, obesity treatment, anti- } \\
\text { inflammatory }\end{array}$ & [109-111] \\
\hline 8. & $\begin{array}{l}\text { Chitin nano-whiskers } \\
(\mathrm{CNW})\end{array}$ & $\begin{array}{l}\text { Treatment of chitin with } \\
3 \mathrm{~N} \mathrm{HCl} \text { at } 100^{\circ} \mathrm{C} \text { or } 3 \mathrm{M} \\
\mathrm{H}_{2} \mathrm{SO}_{4} \text { solution }\end{array}$ & $\begin{array}{l}\text { Nanotechnology and } \\
\text { nanocomposite material for } \\
\text { drug/gene delivery or } \\
\text { nanoscaffolds in tissue } \\
\text { engineering }\end{array}$ & [112-113] \\
\hline 9. & $\begin{array}{l}\text { Chitin nanoparticles } \\
\text { (CNP) }\end{array}$ & $\begin{array}{l}\text { Treatment of chitin in } 3 \mathrm{M} \\
\mathrm{HCl} \text { for } 1.5 \mathrm{~h} \text { at } 90^{\circ} \mathrm{C}\end{array}$ & $\begin{array}{l}\text { Biocompatible, biodegradable, } \\
\text { and non-toxic }\end{array}$ & [114-116] \\
\hline 10 & $\begin{array}{l}\text { Chitin nanocomposites } \\
\text { (CNC) }\end{array}$ & $\begin{array}{l}\text { By chitin whisker and } \\
\text { tannic acid,cross-link } \\
\text { chitosan, or chitin } \\
\text { nanofibers or adding metal } \\
\text { nanoparticles into chitin } \\
\text { matrix }\end{array}$ & $\begin{array}{l}\text { Drug encapsulation, improving } \\
\text { the drug load, and controlled } \\
\text { release action }\end{array}$ & {$[76,117]$} \\
\hline 11. & Chitin hydrogels (CHG) & $\mathrm{NaOH}$ treatment of chitin & $\begin{array}{l}\text { Bone tissue regeneration, cell } \\
\text { scaffolds and drug delivery } \\
\text { vehicles }\end{array}$ & [118-120] \\
\hline
\end{tabular}




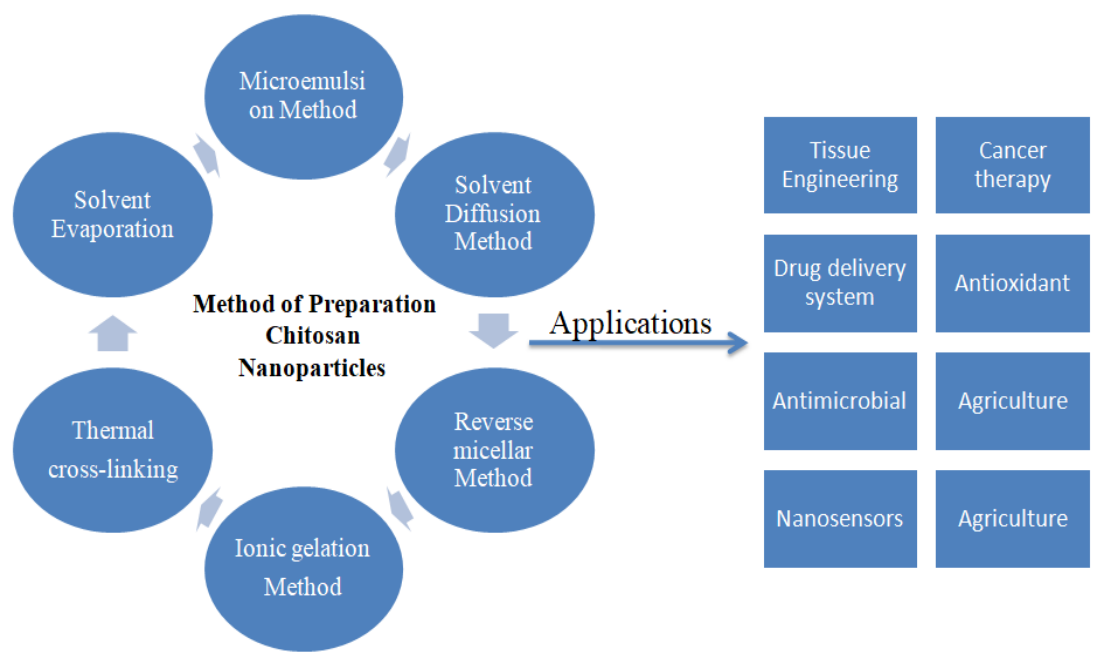

Figure 11. Strategies for production and application of chitosan nanoparticles.

\subsection{Application in sustainable agriculture management.}

\subsubsection{Antifungal activity.}

A highly limiting factor in the production of the crops is the diseases that are caused by the phytopathogenic fungi $[23,25]$. These diseases affect the seeds right from germination and throughout development, consequently reducing the yield by $30 \%$ [121]. Therefore plant disease control has become highly dependent upon the fungicides to control these fungal diseases. The investigation has reported potentially unfavorable environmental side effects. Increased awareness and the concern regarding the accumulation of the residues of these chemical fungicides in the biosphere and also the development of the resistance against conventional antibiotics have done the search for new antimicrobial agents, a field of utmost importance in disease management. Organisms producing chitinase can be exploited as biocontrol agents in both direct and indirect manner by using their purified proteins or via gene manipulation [122]. According to estimation, the crop loss because of disease-causing pathogens is around $25 \%$ of the total yield in the developed countries, and in the developing countries, it is around 50\% [123]. Fungal infections alone cause a threat $\mathrm{f}$ these diseases. Nonspecific toxicity and adverse effects of commercial fungicides on the environment have led our thinking on other options of pest control like the use of chitinases/ chitinolytic enzymes as antifungal agents to control pathogens [19]. The characteristic of chitinases to hydrolyze chitin can be exploited, suggested a greener approach that can be exploited to control plant and fungal pathogens.

Biological control is the most accepted alternative because it is environment friendly. These specific microorganisms are used, which interfere with the plant pathogens and pests and doing so to overcome the problems caused by the chemical methods. Among the microorganisms, the bacteria are considered as the most suitable as they are able to produce a variety of antimicrobial products. The bacterial species of Streptomyces, Bacillus, and Pseudomonas are commonly used as biocontrol agents [124]. There has been a lot of information reported on the antagonism between the bacteria and fungi and about its potential role in biocontrol [125-126]. Some bacterial secretions have the ability to kill the phytopathogenic fungi. These secretions contain many enzymes that lyse the structural component of the fungal cell wall. One of the enzymes in these secretions is chitinase. Chitinase plays an important function in biocontrol of fungal plant diseases by hydrolyzing chitin 
polymer of fungal pathogen's cell walls so that altered fungal growth, hyphal tips, and germ tubes $[24,71,127]$.

The rectified chitinases of Streptomyces rimosus exhibited in vitro antifungal properties against Fusarium solani and Alternaria alternata [128]. Correspondingly, the chitinolytic potential of Streptomyces viridificans, in vitro was observed against Curvularia, Pythium, Colletotrichum, Fusarium Aspergillus, Sclerotinia, and Rhizoctonia [28]. Amongst Streptomyces spp. Recovered from rhizosphere soils, the S. hygroscopicus was effective antagonistic against Colletotrichum gloeosporioides and Sclerotium rolfsii [16]. The dampingoff disease of sugar beet, caused by Rhizoctonia solani, can be controlled in vitro with streptomycetes [129]. It was observed that GH19 chitinases show antifungal properties against fungi: Rhizoctonia solani, Colletotrichum gossypii, Pythium aristosporum, and Fusarium oxysporum. Streptomyces viridodiasticus isolates caused extensive cell wall lysis of Sclerotinia minor when grown in a carbon-free salt solution [27]. These isolates, individually or in combination, decrease disease incidence in greenhouse conditions [130]. The combined effect of chitinolytic enzymes and an antifungal compound, 2-furancarboxaldehyde of Streptomyces cavourensis was found to be a potential biocontrol agent of anthracnose in pepper [131]. An earlier report showed that Bacillus thuringiensis isolates exhibited antifungal activity against Verticillium spp. in-vitro [132]. The isolates of Bacillus cereus reduced the severity of Verticillium wilt on eggplant up to $70 \%$ in 14 days [133]. The endochitinase and chitobiose from Serratia marescens inhibited Botrytis cinerea in vitro. The red pigment Prodigiosin, produced by $S$. marescens, enhanced the rate of inhibition [134]. The damping-off disease of cucumber, which is caused by Phytophthora capsici, also controls by Prodigiosin. The in vitro chitinase activity of Enterobacter spp. was assessed in opposition to the common cocoa leaf pathogen, Colletotrichum gloeosporioides. The in vitro outcomes demonstrated that the contagious hyphae developed in deviant shapes and were broken or lysed, which was probably brought about by in vivo assays, established a decreased severity of the disease [135]. Many chitinolytic bacteria also possess plant-growth-promoting properties, e.g., a Pseudomonas sp. enhances nodulation in chickpea [136].

\subsubsection{Insecticide activity.}

The well-known biocontrol agent of insects in agriculture is Bacillus thuringiensis. Chitinases have also been demonstrated to affect insect growth, which ultimately leads to death [24]. The chitinases were weakening the peritrophic membrane that lines the gut epithelium of the larvae [137]. Brandt et al. found that the Orgyia pseudotsugata peritrophic membrane was besmirched by chitinases, and an equivalent effect was also observed in vivo with Spodoptera littoralis and E. coli that expressed the endochitinase ChiAII from Serratia marescens [138139]. The B. thuringiensis blends two chitinases that improved the insecticidal action of $\mathrm{Bt}$ crystal protein against hatchlings of Spodoptera exigua and Helicoverpa armigera [119, 140]. Bacillus pumilus inhibited the growth of Scirpophaga incertulas, a rice pest [141]. Paenibacillus illinoisensis deformed and destroyed the eggshell of the root-knot nematode (Meloidogyne incognita) [101]. Singh et al. found that Paenibacillus sp. D1, could be used to control Helicoverpa armigera. Stenotrophomonas and Chromobacterium were observed to inhibit egg hatch of the potato cyst nematode (Globodera rostochiensis) in vitro [142-143]. A GH18 chitinase isolated from Pseudomonas sp., had amino acid sequence identity with chitinases of Serratia marescens, showed little insecticidal activity towards Spodoptera litura larvae [144]. 


\subsection{Application in environmental management.}

The biggest source of chitinous waste is the seafood industry. In order to maintain the ecosystem's carbon-nitrogen balance, its recycling is highly essential. The insoluble nature of chitin and its inactivity towards most chemical agents makes it mandatory for the utilization of more feasible biological processes. Keeping the above facts in view, enzyme chitinase can be adequately used for the biological conversion of industrial seafood waste [18]. It executes two functions at the same time in a manner that makes use of chitinous wastes and reduces the production cost of the microbial chitinases [20]. Soil and water pollution by organic and inorganic contaminants affect human health and the environment. Environmental protection is very important nowadays, and industries try to develop new technologies that resolve the contaminants problem [145-147]. Recently chitin and its derivatives were used for remediation of organic and inorganic contaminants from soil and water (Fig. 12). The biocompatible nature of chitins and its derivatives are used for the immobilization of chitinases for sensing the environment hazardous chemicals [148]. Chitin and chitosan help for the removal of dyes, organic and contaminants, and remediation of heavy metals [149-153]. After some modifications like functionalization of chitin is using irradiated grafting of acrylonitrile on chitin, polypyrrole, acetophenone derivatives of nanochitosan, cross-linking chitosan into nanohydrogel, poly, chitin nanofibers having better heavy metal adsorption potential (154156]. Chitinous waste of marine organisms can be converted into simpler useful depolymerized components by chitinases, which reducing water pollution (2, 157-158]. Chito-oligomers obtained by the action of chitinases have a wide range of biotechnological applications in biochemical, food, and various chemical industries (Fig. 12). Chitinase can also be used in the conversion of chitinous waste into biofertilizer, insecticides, and fungicides so that these can be more potent and ecofriendly as compared to chemically synthesized active agents (Fig. 12).

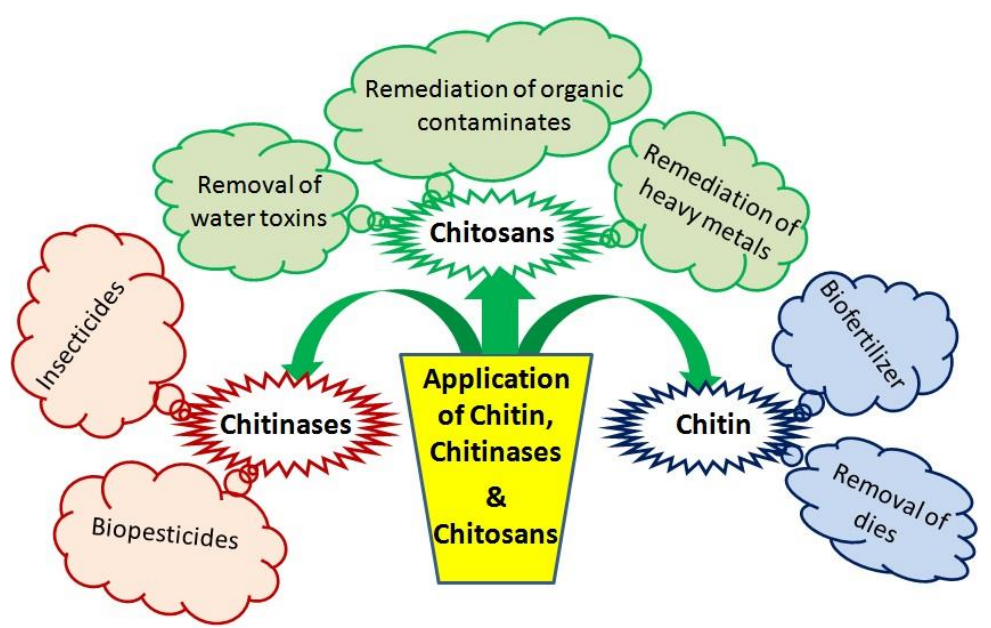

Figure 12. Application of chitin, chitinases, and chitosans for sustainable management of the environment.

\section{Conclusions}

The chitin is naturally available in insects, fungi, and some algae; these are widely used for the manufacturing of chitin; chitinases play a significant role in biocontrol against various fungal pathogens and insects. These can serve as sustainable and eco-friendly alternatives to chemical pesticides. Chitinase producing microorganisms are a potential alternative to these chemicals because they are present in the soil and part of the ecosystem. For the industrial applications, the production of chitinase is carried out in the liquid batch fermentation, 
continuous fermentation, and fed-batch fermentation by chitinolytic microorganisms. Chitin derivatives and chitinases have significant pharmacological values, as an anti-inflammatory drug, antifungal drugs, anticancer, immunity booster, antifungal creams, wound healing, contact lenses, artificial skin, surgical stitches, and used in making artificial medical products because these chitin derivatives have been found to be non-toxic, non-allergic, biocompatible, and biodegradable. In the environmental remediation process, using chitin and its derivatives may lead to the development of futuristic methods to reduce the environmental toxins because these are eco-friendly biodegradable material. Other applications of chitinases include the biological conversions of chitinous waste to the single-cell proteins and ethanol and fertilizers. We hoped that this review would encourage the use of chitin, chitinases, and chitin derivatives for the sustainable development of pharmaceutical, agricultural, and environmental perspectives for the benefit of society and nature.

\section{Funding}

This research received no external funding.

\section{Acknowledgments}

Authors are thankful to the Hon'ble Vice-Chancellor, Maharishi Markandeshwar (Deemed to be University), Mullana-Ambala (HR), India, for encouragement to inter-university research collaboration.

\section{Conflicts of Interest}

The authors declare no conflict of interest.

\section{References}

1. Thakur, N.; Nath, K.; Chauhan, A.; Parmar, S.C.; Pandey, H. Chitinases from microbial sources, their role as biocontrol agents and other potential applications. J. Entomol. Zool. Studies 2019, 7, 837-843.

2. Rathore, A.S.; Gupta, R.D. Chitinases from bacteria to human: Properties, applications, and future perspectives. Enz. Res. 2015, https://doi.org/10.1155/2015/791907.

3. Amin, A.; Ali, S.W.; Arshad, R.; Nadeem, S.; Ali, S. Characterization of chitinolytic bacterial strains isolated from local habitat. Mycopathol. 2011, 9, 51-55.

4. Han, Y.; Yang, B.; Zhang, F.; Miao, X.; Li, Z. Characterization of antifungal chitinase from marine Streptomyces sp. DA11 associated with South China sea sponge Craniella australiensis. Marine Biotechnol. 2009, 11, 132-140, https://doi.org/10.1007/s10126-008-9126-5.

5. Dong, L.Q.; Yang, J.K.; Zhang, K.Q. Cloning and phylogenetic analysis of the chitinase gene from the facultative pathogen Paecilomyces lilacinus. J. Appl. Microbiol. 2007, 103, 1364-5072, https://doi.org/10.1111/j.1365-2672.2007.03514.x.

6. Al-Fassi, F.A.; Ghanem, K.M.; Farsi, R.M. Statistical optimization of cultural conditions for chitinase production from shrimp shellfish waste by Alternaria alternate. Afr. J. Microbiol. Res. 2009, 51, 649-1659, https://doi.org/10.5897/AJMR11.255.

7. Ahmed, N.U.; Park, J.I.; Seo, M.S.; Kumar, T.S.; Lee, I.H. Identification and expression analysis of chitinase genes related to biotic stress resistance in Brassica. Mol. Biol. Rep. 2012, 39, 36493657, https://doi.org/10.1007/s11033-011-1139-x.

8. Mishra., A.K.; Pandey, B.; Tyagi, C.; Chakraborty, O.; Kumar, A. Structural and functional analysis of chitinase gene family in wheat (Triticum aestivum). Ind. J. Biochem. Biophys. 2015, 52, 169-178, http://hdl.handle.net/123456789/31528.

9. Roopavathi, A.S.; Vigneshwari, R.; Jayapradha, R.; Chitinase: Production and applications. J. Chem. Pharma. Res. 2015, 7, 924-931.

10. Saima, K.; Roohi, M. ; Ahmad, I.Z. Isolation of novel chitinolytic bacteria and production optimization of extracellular chitinase. J. Genet. Engin. Biotechnol. 2013, 11, 39-46, http://dx.doi.org/10.1016/j.jgeb.2013.03.001.

11. Jholapara, R.J.; Mehta, R.S.; Sawant, C.S. Optimization of cultural conditions for chitinase production 
from chitinolytic bacteria isolated from soil sample. Int. J. Pharma. Bio. Sci. 2013, 4, 464-471.

12. Gupta, M.; Aziz, M.N.; Choudhary, D.K.; Shrivastava, N.; Varma, A. Identification of chitin degrading bacterial strains isolated from bulk and rhizospheric soil. J. Pure Appl. Microbiol. 2018, 12, 133-141, https://dx.doi.org/10.22207/JPAM.12.1.17.

13. Dahiya, N.; Tewari, R.; Tiwari, R.P.; Hoondal, G.S. Chitinase from Enterobacter sp. NRG4: Its purification, characterization and reaction pattern. Elect. J. Biotechnol. 2005, 8, 134-145, https://doi.org/10.2225/vol8-issue2-fulltext-6

14. Fadhil, L.; Kadim, A.; Mahdi, A. Production of chitinase by Serratia marcescens from soil and its antifungal activity. J. Nat. Sci. Res. 2014, 4, 80-86. https://doi.org/10.7176/JNSR/2014.8.12635.4.

15. Cody, R.M. Distribution of chitinase and chitobiose in Bacillus. Curr. Microbiol. 1989, 19, 201-205, https://doi.org/10.1007/BF01570162.

16. Parapagdee, B.; Kuekulvong, C.; Mongkolsuk, S. Antifungal potential of extracellular metabolites produced by Streptomyces hygroscopicus against phytopathogenic fungi. Int. J. Biol. Sci. 2008, 4, 330337, https://doi.org/10.7150/ijbs.4.330.

17. Devi, C.S., Srinivasan, V.M.; Archana, B.; Roy, S.S.; Naine, S.J. Production and partial purification of antifungal chitinase from Bacillus cereus VITSD3. Bio. Sci. J. 2014, 31, 960-968, https://doi.org/10.14393/BJ-v31n3a2015-26263.

18. Nawani, N.N.; Kapadnis, B.P.; Das, A.D.; Rao, A.S.; Mahajan, S.K. Purification and characterization of a thermophilic and acidophilic chitinase from Microbispora sp. V2. J. App. Microbiol. 2002, 93, 965-975, https://doi.org/10.1046/j.1365-2672.2002.01766.x.

19. Huang, C.J.; Wang, T.K.; Chung, S.C.; Chen, C.Y. Identification of an antifungal chitinase from a potential biocontrol agent, Bacillus cereus 28-9. J. Biochem. Mol. Biol. 2005, 38, 82-88.

20. Bansode, V.B.; Bajekal, S.S. Characterization of chitinases from microorganisms isolated from the Lonar Lake. Ind. J. Biotechnol. 2006, 5, 357-363, http://hdl.handle.net/123456789/5596.

21. Vega, K.; Kalkum, M. Chitin, Chitinase responses, and invasive fungal infections. Int. J. Microbiol. 2011, 1-10, https://doi.org/10.1155/2012/920459.

22. Wang, Y.; Choi, J.Y.; Roh, J.Y.; Tao, X.Y.; Liu, Q. Insecticidal activity of the chitinase from the Spodopter litura nucleopolyhedro virus. Entomol. Res. 2013, 431, 63-69.

23. Das, M.P.; Devi, P.V.; Yasmine, Y. A study on antagonistic potential of bacteria against phytopathogenic fungi. Int. J. Pharma Sci. Rev. Res. 2015, 34, 191-193, https://pdfs.semanticscholar.org/44c6/f66e45b2d38fef4f80f3b3b847bbc9e818cc.pdf.

24. Khatri, D.K.; Tiwari, D.N.; Bariya, H.S. Chitinolytic efficacy and secretion of cell wall-degrading enzymes from Trichoderma spp. in response to phytopathological fungi. J. Appl. Biol. Biotechnol. 2017, 5, 1-8, https://doi.org/10.7324/JABB.2017.50601.

25. Veliz, E.A.; Hidalgo, P.M.; Hirsch, A.M. Chitinase-producing bacteria and their role in biocontrol. AIMS Microbiol. 2017, 3, 689-705. https://doi.org/10.3934/microbiol.2017.3.689

26. Karunya, S.K.; Reetha, D.; Saranraj, P.; Milton, D.J. Optimization and purification of chitinase produced by Bacillus subtilis and its antifungal activity against plant pathogens. Int. J. Pharma. Biol. Arch. 2011, 2, 1680-1685.

27. Gherbawy, Y.; Elhariry, H.; Altalhi, A.; El-Deeb, B.; Khiralla, G. Molecular screening of Streptomyces isolates for antifungal activity and family 19 chitinase enzymes. J. Microbiol. 2012, 50, 459-468, https://doi.org/10.1007/s12275-012-2095-4.

28. Gupta, R.; Saxena, R.; Chaturvedi, P.; Virdi, J. Chitinase production by Streptomyces viridificans: Its potential in fungal cell wall lysis. J. Appl. Bacteriol. 1995, 78, 378-83, https://doi.org/10.1111/j.13652672.1995.tb03421.x.

29. Khor, E.; Lim, L.Y. Implantable applications of chitin and chitosan. Biomater. 2003, 24, 2339-2349, https://doi.org/10.1016/s0142-9612(03)00026-7.

30. Rameshthangam, P.; Solairaj, D.; Arunachalam, G.; Ramasamy, P. Chitin and Chitinase: Biomedical and environmental applications of chitin and its derivatives. J. Enz. 2018, 1, 20-43, https://doi.org/10.14302/issn.2690-4829.jen.-18-2043.

31. Rudrapatnam, N.T.; Farooqahmed, S.K. Chitin: The undisputed biomolecule of great potential. Crit. Rev. Food Sci. Nutri. 2003, 43, 61-87, https://doi.org/10.1080/10408690390826455.

32. Messner, R.; Kubicek, C.P. Synthesis of cell wall glucan, chitin, and protein by regenerating protoplasts and mycelia of Trichoderma reesei. Can. J Microbiol. 1990, 36, 211-217, https://doi.org/10.1139/m90036.

33. Ruiz-Flores, E.; Lopez-Romero, E.; Gutierrez-Corona, F. Chitin synthetase activity in a developmental mutant of Phycomyces blakesleeanus. Antonie van Leeuwenhoek 1990, 58, 67-72, https://doi.org/10.1007/BF00422719.

34. Muzzarelli, R.A.; Ilari, P.; Tarsi, R.; Dubini, B.; Xia, W. Chitosan from Absidia coerulea. Carbohydr. Polym. 1994, 25, 45-50, https://doi.org/10.1016/0144-8617(94)90161-9.

35. Kaplan, D.L. Biopolymers from renewable resources, $1^{\text {st }}$ ed; Springer: Verlag Berlin Heidelberg, 1998; 629-638, https://doi.org/10.1007/978-3-662-03680-8.

36. Svitil, A.L.; Kirchman, D.L. A chitin-binding domain in a marine bacterial chitinase and other microbial 
chitinases: implications for the ecology and evolution of 1,4-glycanases. Microbiol. 1998, 144, 1299-1308, https://doi.org/10.1099/00221287-144-5-1299.

37. Rhazi, M.; Desbrieres, J.; Tolaimate, A.; Alagui, A.; Vottero, P. Investigation of different natural sources of chitin: influence of the source and deacetylation process on the physicochemical characteristics of chitosan. Polym. Int. 2000, 49, 337-344, https://doi.org/10.1002/(SICI)10970126(200004)49:4<337::AID-PI375>3.0.CO;2-B.

38. Zhang. M.; Haga, A.; Sekiguchi, H.; Hirano, S. Structure of insect chitin isolated from beetle larva cuticle and silkworm (Bombyx mori) pupa exuvia. Int. J. Biol. Macromol. 2000, 27, 99-105, https://doi.org/10.1016/s0141-8130(99)00123-3.

39. Maw, T.; Tan, T.K.; Khor, E.; Wong, S.M. Selection of Gongronella butleri strains for enhanced chitosan yield with UV mutagenesis. J. Biotechnol. 2002, 95, 189-193, https://doi.org/10.1016/s01681656(02)00004-4.

40. Percot, A.; Viton, C.; Domard, A. Optimization of chitin extraction from shrimp shells. Biomacromol. 2003, 4, 12-18, https://doi.org/10.1021/bm025602k.

41. Nemtsev, S.V.; Zueva, O.Y.; Khismatullin, M.R.; Albulov, A.I.; Varlamov, V.P. Isolation of chitin and chitosan from honeybees. Appl. Biochem. Microbiol. 2004, 40, 39-43, https://doi.org/10.1023/B:ABIM.0000010349.62620.49.

42. Raabe, D.; Al-Sawalmih, A.; Yi, S.B.; Fabritius, H. Preferred crystallographic texture of $\alpha$-chitin as a microscopic and macroscopic design principle of the exoskeleton of the lobster Homarus americanus. Acta Biomater. 2007, 3, 882-895, https://doi.org/10.1016/j.actbio.2007.04.006.

43. Auerswald, L.; Gade, G. Simultaneous extraction of chitin and astaxanthin from waste of lobsters Jasus lalandii, and use of astaxanthin as an aquacultural feed additive. Afr. J. Marine Sci. 2010, 30, 35-44, https://doi.org/10.2989/AJMS.2008.30.1.4.454.

44. Gabius, H.J. The sugar code: Fundamentals of glycosciences; John Wiley \& Sons: United States. 2011, www.wiley-vch.de/home/thesugarcode-p-9783527320899.

45. Kumaresapillai, N.; Basha, R.A.; Sathish, R. Production and evaluation of chitosan from Aspergillus niger MTCC strains. Iran. J. Pharma. Res. 2011, 10, 553-558, https://doi.org/10.22037/IJPR.2011.1003.

46. Ramanathan, A.; Kittusamy, R. Antihepatotoxic effect of isolated chitin from Rhizopus oryzae against paracetamol-induced hepatotoxicity. Bangladesh J. Pharm. 2011, 6, 6467, https://doi.org/10.3329/bjp.v6i1.8556

47. Cahu, T.B.; Santos, S.D.; Mendes, A.; Cordula, C.R.; Chavante, S.F. Recovery of protein, chitin, carotenoids and glycosaminoglycans from Pacific white shrimp (Litopenaeus vannamei) processing waste. Process. Biochem. 2012, 47, 570-577, https://doi.org/10.1016/j.procbio.2011.12.012.

48. Liu, S.; Sun, J.; Yu, L.; Zhang, C.; Bi, J. Extraction and characterization of chitin from the beetle Holotrichia parallela Motschulsky. Mol. 2012, https://doi.org/10.3390/molecules17044604.

49. Puvvada, Y.S.; Vankayalapati, S.; Sukhavasi, S. Extraction of chitin from chitosan from exoskeleton of shrimp for application in the pharmaceutical industry. Int. Curr. Pharm. J. 2012, 1, 258-263, https://doi.org/10.3329/icpj.v1i9.11616.

50. Sorokoumov, I.; Zagorskiy, I.; Zagorskaya, D.; Uryash, V.; Kokurina, N. Physicochemical properties of chitin isolated from shell of industrial crabs of various species. Prog. Chem. Appl. Chitin Derivat. 2014, $15,5-10$.

51. Vaingankar, P.N.; Juvekar, A.R. Fermentative production of mycelial chitosan from zygomycetes: Media optimization and physico-chemical characterization. Adv. Biosci. Biotechnol. 2014, 5, 940-956, https://doi.org/10.4236/abb.2014.512108.

52. Shanmugam, K.A. Modified process for deprotinization of green grab shells (Carcinus maenas) extraction of chitin/chitosan. J. Chem. Pharm. Sci. 2016, 9, 163-165.

53. Solairaj, D.; Rameshthangam, P.; Srinivasan, P. Adsorption of methylene blue, bromophenol blue, and coomassie brilliant blue by $\alpha$-chitin nanoparticles. J. Adv. Res. 2016, 7, 113-124, https://doi.org/10.1016/j.jare.2015.03.003.

54. Shaikh, S.A.; Deshpande, M.V. Chitinolytic enzymes: Their contribution to basic and applied research. World J. Microbiol. Biotechnol. 1993, 9, 468-475, https://doi.org/10.1007/BF00328035.

55. Bhattacharya, S.; Chakrabortty, S.; Das, A. Optimization of process parameters for chitinase production by a marine isolate of Serratia marcescens. Int. J. Pharma. Bio. Sci. 2007, 2, 8-20.

56. Fukamizo, T.; Sakai, C.; Tamoi, M. Plant chitinases: Structure-function relationships and their physiology. Foods Food Ingred. J. Jpn. 2003, 208, 631-632.

57. Shamshina, J.L.; Kelly, A.; Oldham, T.; Rogers, R.D. Agricultural uses of chitin polymers. Environ. Chem. Lett. 2020, 18, 53-60, https://doi.org/10.1007/s10311-019-00934-5.

58. Yang, J.; Gan, Z.; Lou, Z.; Tao, N.; Mi, Q. Crystal structure and mutagenesis analysis of chitinase CrChi1 from the nematophagous fungus Clonostachys rosea in complex with the inhibitor caffeine. Microbiol. 2010, 156, 3566-3574, https://doi.org/10.1099/mic.0.043653-0.

59. Saito, A.; Ooya, T.; Miyatsuchi, D.; Fuchigami, H. Molecular characterization and antifungal activity of a family 46 chitosanase from Amycolatopsis sp. CsO-2. Fed. Eur. Med. Sci. Microbiol. Lett. 2009, 293, 79- 
84, https://doi.org/10.1111/j.1574-6968.2009.01507.x.

60. Jarach, N.; Dodiuk, H.; Kenig, S. Polymers in the medical antiviral front-line. Polymers 2020, 12, 1727 , https://doi.org/10.3390/polym12081727.

61. Hidangmayum, A.; Dwivedi, P.; Katiyar, D.; Hemantaranjan, A. Application of chitosan on plant responses with special reference to abiotic stress. Physiol.Mol. Biol. Plants 2019, 25, 313-326, https://doi.org/10.1007/s12298-018-0633-1.

62. Guo, Y.; Dong, Y.; Xu, C.; Xie, Q.; Xie, Y.; Xia, Z.; An, M.; Wu, Y. Novel combined biological antiviral agents cytosinpeptidemycin and chitosan oligosaccharide induced host resistance and changed movement protein subcellular localization of tobacco mosaic virus. Pestic. Biochem. Physiol. 2020, 164, 40-46, https://doi.org/10.1016/j.pestbp.2019.12.006.

63. Gooday, G.W. Physiology of microbial degradation of chitin and chitosan. Biodeg. 1990, 1, 177-190, https://doi.org/10.1007/BF00058835.

64. Shimono, K.; Matsuda, H.; Kawamukai, M. Functional expression of chitinase and chitosanase, and their effects on morphologies in the yeast Schizosaccharomyces pombe. Biosci. Biotechnol. Biochem. 2002, 66, 1143-1147, https://doi.org/10.1271/bbb.66.1143.

65. Gooday, G.W.; Humphreys, A.M.; McIntosh, W.M. Roles of chitinases in fungal growth. Chitin Nat. Technol. 1986, 83-84, https://doi.org/10.1007/978-1-4613-2167-5_12.

66. Hamid, R.; Khan, M.A.; Ahmad, M.; Ahmad, M.M.; Abdin, M.Z. Chitinases: An update. J. Pharm. Bioall. Sci. 2013, 5, 21-29, https://doi.org/10.4103/0975-7406.106559.

67. Juliano, C.; Magrini, G.A. Methylglyoxal, the major antibacterial factor in manuka honey: An alternative to preserve natural cosmetics? Cosmetics. 2019, 6, 1, https://doi.org/10.3390/cosmetics6010001.

68. Madni, A.; Khan, R.; Ikram, M.; Naz, S.S.; Khan, T.; Wahid, F. Fabrication and characterization of chitosan-vitamin c-lactic acid composite membrane for potential skin tissue engineering. Int. J. Polymer Sci. 2019, https://doi.org/10.1155/2019/4362395.

69. Hosseini, S.F.; Nahvi, Z.; Zandi, M. Antioxidant peptide-loaded electrospun chitosan/poly(vinyl alcohol) nanofibrous mat intended for food biopackaging purposes. Food Hydrocolloid. 2019, 89, 637-648, https://doi.org/10.1016/j.foodhyd.2018.11.033.

70. Li, X.; Sun, J.; Che, Y.; Lu, Y.; Liu, F. Antibacterial properties of chitosan chloride-graphene oxide composites modified quartz sand filter media in water treatment. Int. J. Biol. Macromol. 2019, 121, 760773, https://doi.org/10.1016/j.ijbiomac.2018.10.123.

71. Kosowska, K.; Domalik-Pyzik, P.; Krok-Borkowicz, M.; Chłopek, J. Polylactide/hydroxyapatite nonwovens incorporated into chitosan/graphene materials hydrogels to form novel hierarchical scaffolds. Int. J. Mol. Sci. 2020, 21, 2330, https://doi.org/10.3390/ijms21072330.

72. Serrano-Sevilla, I.; Artiga, Á.; Mitchell, S.G.; De Matteis, L.; de la Fuente, J.M. Natural polysaccharides for siRNA delivery: Nanocarriers based on chitosan, hyaluronic acid, and their derivatives. Mol. 2019, 24, 2570, https://doi.org/10.3390/molecules24142570.

73. Fakhri, E.; Eslami, H.; Maroufi, P.; Pakdel, F.; Taghizadeh, S.; Ganbarov, K.; Yousefi, M.; Tanomand, A.; Yousefi, B.; Mahmoudi, S.; Kafil, H.S. Chitosan biomaterials application in dentistry. Int. J. Biol. Macromol. 2020, 162, 956-974, https://doi.org/10.1016/j.ijbiomac.2020.06.211.

74. Roy, H.; Nayak, B.S.; Nandi, S. Chitosan anchored nanoparticles in current drug development utilizing computer-aided pharmacokinetic modeling: Case studies for target specific cancer treatment and future prospective. Curr. Pharm. Des. 2020, 26, 1666-1675, https://doi.org/10.2174/1381612826666200203121241.

75. Prabavathy, V.R.; Mathivanan, N.; Sagadevan, E.; Murugesan, K.; Kumari, D.L. Self-fusion of protoplasts enhances chitinase production and biocontrol activity in Trichoderma harzianum. Biores. Technol. 2006, 97, 2330-2334, https://doi.org/10.1016/j.biortech.2005.10.031.

76. Rubentheren, V.; Ward, T.A.; Chee, C.Y.; Tang, C.K. Processing and analysis of chitosan nanocomposites reinforced with chitin whiskers and tannic acid as a cross linker. Carbohydr. Polym. 2015, 115, 379-387, https://doi.org/10.1016/j.carbpol.2014.09.007.

77. Gooday, G.W. Aggresive and defensive roles for chitinases. In: Chitin Enzymology; Muzzarelli R.A. Ed.; Italia: Atec Edizioni. 1996, 125-133, https://doi.org/10.1007/978-3-0348-8757-1_11.

78. Garg, N.; Gupta, H. Isolation and purification of fungal pathogen (Macrophomina phaseolina) induced chitinase from moth beans (Phaseolus aconitifolius). J. Pharm. Bioall. Sci. 2010,2, 3843. https://doi.org/10.4103/0975-7406.62708.

79. Bhushan, B. Isolation, purification, characterization and scale-up production of a thermostable chitinase from an alkalophilic microorganism. Ph.D. Thesis, Panjab University, India, 1998.

80. Saekhor, K.; Udomsinprasert, W.; Honsawek, S.; Tachaboonyakiat, W. Preparation of an injectable modified chitosan-based hydrogel approaching for bone tissue engineering. Int. J. Biol. Macromol. 2019, 123, 167-173, https://doi.org/10.1016/j.ijbiomac.2018.11.041.

81. Detsi, A.; Kavetsou, E.; Kostopoulou, I.; Pitterou, I.; Pontillo, A.R.N.; Tzani, A.; Christodoulou, P.; Siliachli, A.; Zoumpoulakis, P. Nanosystems for the encapsulation of natural products: The case of chitosan biopolymer as a matrix. Pharma. 2020, 12, 669, https://doi.org/10.3390/pharmaceutics12070669.

82. Dahiya, N.; Tewari, R.; Hoondal, G.S. Biotechnological aspects of chitinolytic enzymes: A review. Appl. 
Microbiol. Biotechnol. 2006, 71, 773-782. https://doi.org/10.1007/s00253-005-0183-7.

83. Vicencio, A.G.; Tsirilakis, K.; Kim, C.; Andrade, C.; Casadevall, A. Methylxanthine chitinase inhibition and antifungal effects. Mycopathol. 2008, 173, 83-91.

84. Di Rosa, M.; Brundo, V.M.; Malaguarnera, L. New insights on chitinases immunologic activities. World J. Immunol. 2016, 6, 96-104, https://doi.org/10.5411/wji.v6.i2.96.

85. Adour, L.; Arbia, W.; Amrane, A.; Mameri, N. Combined use of waste materials: Rcovery of chitin from shrimp shells by lactic acid fermentation supplemented with date juice waste or glucose. J. Chem. Technol. Biotechnol. 2008, 183, 1664-1669, https://doi.org/10.1002/jctb.1980.

86. Sudha, P.N. Chitin/chitosan and derivatives for wastewater treatment. In: Chitin, chitosan, oligosaccharides and their derivatives: Biological activities and applications, Kim, S.K., Ed., CRC Press. 2010, 561-585.

87. Antonino de Queiroz, R.C.M.; Lia Fook, B.R.P.; de Oliveira Lima, V.A.; de Farias Rached, R.I.; Lima, E.P.N. Preparation and characterization of chitosan obtained from shells of shrimp (Litopenaeus vannamei Boone). Marine Drugs. 2017, 141, 1-12, https://doi.org/10.3390/md15050141.

88. Motiei, M.; Kashanian, S.; Lucia, L.A.; Khazaei, M. Intrinsic parameters for the synthesis and tuned properties of amphiphilic chitosan drug delivery nanocarriers. J. Control. Release. 2017, 260, 213-225, https://doi.org/10.1016/j.jconrel.2017.06.010.

89. Senel, S.; McClure, S.J. Potential applications of chitosan in veterinary medicine. Adv. Drug Deliv. Rev. 2004, 56, 1467-1480, https://doi.org/10.1016/j.addr.2004.02.007.

90. Sheng, J., Han, L.; Qin, J., Ru, G.; Li, R., Wu, L.; Cui, D., Yang, P.; He, Y.; Wang, J. N-trimethyl chitosan chloride-coated PLGA nanoparticles overcoming multiple barriers to oral insulin absorption. ACS Appl. Mater. Interf. 2015, 7, 15430-15441, https://doi.org/10.1021/acsami.5b03555.

91. Diebold, Y.; Jarrin, M.; Saez, V.; Carvalho, E.L.; Orea, M. Ocular drug delivery by liposome-chitosan nanoparticle complexes (LCS-NP). Biomater. 2007, 28, 1553-1564, https://doi.org/10.1016/j.biomaterials.2006.11.028.

92. Kean, T.; Thanou, M. Biodegradation, biodistribution and toxicity of chitosan. Adv. Drug Deliv. Rev. 2010, 62, 3-11, https://doi.org/10.1016/j.addr.2009.09.004.

93. Woraphatphadung, T.; Sajomsang, W.; Rojanarata, T.; Ngawhirunpat, T.; Tonglairoum, P. Development of chitosan-based ph-sensitive polymeric micelles containing curcumin for colon-targeted drug delivery. AAPS Pharm. Sci. Tech. 2018, 19, 991-1000, https://doi.org/10.1208/s12249-017-0906-y.

94. Yan, L.; Crayton, S.H.; Thawani, J.P.; Amirshaghaghi, A.; Tsourkas, A. A pH-responsive drug-delivery platform based on glycol chitosan-coated liposomes. Small. 2015, 11, 4870-4874, https://doi.org/10.1002/smll.201501412.

95. Zhao, X.; Zhou, L;, Li, Q.; Zou, Q.; Du, C. Biomimetic mineralization of carboxymethyl chitosan nanofibers with improved osteogenic activity in vitro and in vivo. Carbohydr. Polym. 2018, 195, 225-234, https://doi.org/10.1016/j.carbpol.2018.04.090.

96. Ali, A.; Ahmed, S. A review on chitosan and its nanocomposites in drug delivery. Int. J. Biol. Macromol. 2018, 109, 273-286, https://doi.org/10.1016/j.ijbiomac.2017.12.078.

97. Ho, D.K.; Frisch, S.; Biehl, A.; Terriac, E.; De Rossi, C. Farnesylated glycol chitosan as a platform for drug delivery: Synthesis, characterization, and investigation of mucus-particle interactions. Biomacromol. 2018, 19, 3489-3501.

98. Kalaivani, R.; Maruthupandy, M.; Muneeswaran, T.; Singh, M.; Sureshkumar, S. Chitosan mediated gold nanoparticles against pathogenic bacteria, fungal strains and MCF-7 cancer cells, Int. J. Biol. Macromol. 2020, 146, 560-568, https://doi.org/10.1016/j.ijbiomac.2020.01.037.

99. Kurita, K.; Mori, S.; Nishiyama, Y.; Harata, M. N-Alkylation of chitin and some characteristics of the novel derivatives. Polym. Bull. 2002, 48, 159-166, https://doi.org/10.1007/s00289-002-0015-1.

100. Barikani, M.; Oliaei, E.; Seddiqi, H.; Honarkar, H. Preparation and application of chitin and its derivatives: A review. Iran. Polym. J. 2014, 23, 307-326. https://doi.org/10.1007/s13726-014-0225-z.

101. Jung, W.J.; Jung, S.J.; An, K.N.; Jin, Y.L.; Park, R.D. Effect of chitinase-producing Paenibacillus illinoisensis KJA-424 on egg hatching of root-knot nematode (Meloidogyne incognita). J. Microbiol. Biotechnol. 2002, 12, 865-871.

102. Zou, Y.; Khor, E. Preparation of sulfated-chitins under homogeneous conditions. Carbohydr. Polym. 2009, 77, 516-525, https://doi.org/10.1016/j.carbpol.2009.01.031.

103. Castagnino, E.; Ottaviani, M.F.; Cangiotti, M.; Morelli, M.; Casettari, L. Radical scavenging activity of 5methylpyrrolidinone chitosan and dibutyryl chitin. Carbohydr. Polym. 2008, 74, 640-647, https://doi.org/10.1016/j.carbpol.2008.04.016.

104. Bhatt, L.R.; Kim, B.M.; Hyun, K.; Kang, K.H.; Lu, C. Preparation of chitin butyrate by using phosphoryl mixed anhydride system. Carbohydr. Res. 2011, 346, 691-694, https://doi.org/10.1016/j.carres.2011.01.033.

105. Pillai, C.K.S.; Paul, W.; Sharma, C.P. Chitin and chitosan polymers: Chemistry, solubility and fiber formation. Prog. Polym. Sci. 2009, 34, 641-678, https://doi.org/10.1016/j.progpolymsci.2009.04.001.

106. Huang, X.; Wu, Y.; Wei, S.; Chen, Q.; Liu, C. The effect of carboxymethyl chitin on sustained drug release of aspirin tablet. Mater. Lett. 2012, 66, 206-208.

107. Chae, S.Y.; Jang, M.K.; Nah, J.W. Influence of molecular weight on oral absorption of water soluble 
chitosans. J. Control Release 2005, 102, 383-394, https://doi.org/10.1016/j.jconrel.2004.10.012.

108. Mourya, V.K.; Inamdar, N.N.; Choudhari, Y.M. Chitooligosaccharides: Synthesis, characterization and applications. Polym. Sci. Ser. A. 2011, 53, 583-612, https://doi.org/10.1134/S0965545X11070066.

109. Ifuku, S.; Nogi, M.; Abe, K.; Yoshioka, M.; Morimoto, M. Preparation of chitin nanofibers with a uniform width as $\alpha$-chitin from crab shells. Biomacromol. 2009, 10, 1584-1588.

110. Azuma, K.; Osaki, T.; Wakuda, T.; Ifuku, S.; Saimoto, H. Beneficial and preventive effect of chitin nanofibrils in a dextran sulfate sodium- induced acute ulcerative colitis model. Carbohydr. Polym. 2012, 87, 1399-1403, https://doi.org/10.1016/j.carbpol.2011.09.036.

111. Ifuku, S.; Saimoto, H. Chitin nanofibers: Preparations, modifications, and applications. Nanoscale. 2012, 4, 3308-3318.

112. Mincea, M.; Negrulescu, A.; Ostafe, V. Preparation, modification, and applications of chitin nanowhiskers: A review. Rev. Adv. Mater. Sci. 2012, 30, 225-242.

113. Qin, Y.; Zhang, S.; Yu, J.; Yang, J.; Xiong, L. Effects of chitin nano-whiskers on the antibacterial and physicochemical properties of maize starch films. Carbohydr. Polym. 2016, 147, 372-378, https://doi.org/10.1016/j.carbpol.2016.03.095.

114. Goodrich, J.D.; Winter, W.T. Alpha-chitin nanocrystals prepared from shrimp shells and their specific surface area measurement. Biomacromol. 2007, 8, 252-257, https://doi.org/10.1021/bm0603589.

115. Smitha, K.T.; Anitha, A.; Furuike, T.; Tamura, H.; Nair, S.V. In vitro evaluation of paclitaxel loaded amorphous chitin nanoparticles for colon cancer drug delivery. Colloids Surf. B. 2013, 104, 245-253, https://doi.org/10.1016/j.colsurfb.2012.11.031.

116. Smitha, K.T.; Nisha, N.; Maya, S.; Biswas, R.; Jayakumar, R. Delivery of rifampicin-chitin nanoparticles into the intracellular compartment of polymorphonuclear leukocytes. Int. J. Biol. Macromol. 2015, 74, 3643, https://doi.org/10.1016/j.ijbiomac.2014.11.006.

117. Bogdanova, O.I., Polyakov, D.K., Streltsov, D.R.; Kulebyakina, A.I.; Orekhov, A.S. Fabrication and mechanical properties of composite based on $\beta$-chitin and polyacrylic acid. Carbohydr. Polym. 2017, 157, 1496-1502, https://doi.org/10.1016/j.carbpol.2016.11.032.

118. Kawata, M.; Azuma, K.; Izawa, H.; Morimoto, M.; Saimoto, H. Biomineralization of calcium phosphate crystals on chitin nanofiber hydrogel for bone regeneration material. Carbohydr. Polym. 2016, 136, 964969, https://doi.org/10.1016/j.carbpol.2015.10.009.

119. Liu, H.; Liu, J.; Qi, C.; Fang, Y.; Zhang, L. Thermosensitive injectable in-situ forming carboxymethyl chitin hydrogel for three-dimensional cell culture. Acta Biomater. 2016, 35, 228-237. https://doi.org/10.1016/j.actbio.2016.02.028.

120. Wang, Q.; Chen, S.; Chen, D. Preparation and characterization of chitosan based injectable hydrogels enhanced by chitin nano-whiskers. J. Mech. Behav. Biomed. Mater. 2017, 65, 466-477, https://doi.org/10.1016/j.jmbbm.2016.09.009.

121. Khokhar, I.; Haider, M.S.; Ali, A.; Mukhtar, I.; Mushtaq, S. Evaluation of Antagonistic activity of soil bacteria against plant pathogenic fungi. Pak. J. Phytopathol. 2011, 23, 166-169.

122. Singh, A.; Gohel, V.; Vimal, M.; Ashwini, P.; Chhatpar, H.S. Bioprospecting and antifungal potential of chitinolytic microorganisms. Afr. J. Biotechnol. 2005, 5, 54-72, http://www.academicjournals.org/AJB.

123. Gohel, V.; Singh, A. Vimal, M.; Ashwini, P.; Chhatpar, H.S. Bioprospecting and antifungal potential of chitinolytic Microorganisms. Afr. J. Biotechnol. 2006, 5, 54-72, https://www.ajol.info/index.php/ajb/article/view/137726.

124. Paulitz, T.C.; Belanger, R.R. Biological control in greenhouse systems. Annu. Rev. Phytopathol. 2001, 39 , 103-133, https://doi.org/10.1146/annurev.phyto.39.1.103.

125. Liu, D.; Cai, J.; Xie, C.; Liu, C.; Chen, Y. Purification and partial characterization of a 36-kDa chitinase from Bacillus thuringiensis subsp. colmeri, and its biocontrol potential. Enz. Microbiol. Technol. 2010, 46, 252-256, https://doi.org/10.1016/j.enzmictec.2009.10.007.

126. Mishra, D.S.; Kumar, A.; Prajapati, C.R.; Singh, A.K.; Sharma, S.D. Identification of compatible bacterial and fungal isolate and their effectiveness against plant diseases. J. Environ. Biol. 2011, 34, 183-189, https://pubmed.ncbi.nlm.nih.gov/24620577/.

127. Das, S.; Singh, V.K.; Dwivedy, A.K.; Chaudhari, A.K.; Upadhyay, N.; Singh, P.; Sharma, S.; Dubey, N.K. Encapsulation in chitosan-based nanomatrix as an efficient green technology to boost the antimicrobial, antioxidant and in situ efficacy of Coriandrum sativum essential oil. Int. J. Biol. Macromol. 2019, 133, 294-305, https://doi.org/10.1016/j.ijbiomac.2019.04.070.

128. Brzezinska, M.S.; Jankiewicz, U.; Walczak, M. Biodegradation of chitinous substances and chitinase production by the soil actinomycete Streptomyces rimosus. Int. Biodet. Biodeg. 2013, 84, 104110, https://doi.org/10.1016/j.ibiod.2012.05.038.

129. Sadeghi, A.; Hessan, A.R.; Askari, H. Biological control potential of two Streptomyces isolates on Rhizoctonia solani, the causal agent of damping-off of sugar beet. Pak. J. Biol. Sci. 2006, 9, 904-910, https://doi.org/10.3923/pjbs.2006.904.910.

130. El-Tarabily, K.A.; Soliman, M.H.; Nassar, A.H.; Al-Hassani, H.A.; Sivasithamparam, K. Biological control of Sclerotinia minor using a chitinolytic bacterium and actinomycetes. Plant Pathol. 2000, 49, 573583, https://doi.org/10.1046/j.1365-3059.2000.00494.x. 
131. Lee, S.Y.; Tindwa, H.; Lee, Y.S.; Kyaw, W.N.; Seong, H.H. Biocontrol of anthracnose in pepper using chitinase, beta-1,3 glucanase, and 2-furancarboxaldehyde produced by Streptomyces $\begin{array}{llll}\text { cavourensis SY224. J. Microbiol. } & \text { Biotechnol. 2012, } & \text { 22, }\end{array}$ https://doi.org/10.4014/jmb.1203.02056.

132. Hollensteiner, J.; Wemheuer, F.; Harting, R.; Kolarzyk, A.M.; Valerio, S.M.D. Bacillus thuringiensis and Bacillus weihenstephanensis inhibit the growth of $\begin{array}{llll}\text { phytopathogenic Verticillium species. Front. } & \text { Microbiol. } & \text { 2017, }\end{array}$ 2171p, https://doi.org/10.3389/fmicb.2016.02171.

133. Li, J.G.; Jiang, Z.Q.; Xu, P.; Sun, F.F., Guo, J.H. Characterization of chitinase secreted by Bacillus cereus strain $\mathrm{CH} 2$ and evaluation of its efficacy against Verticillium wilt of eggplant. Biocontrol. 2008, 53, 931-944, https://doi.org/10.1007/s10526-007-9144-7.

134. Someya, N.; Nakajima, M.; Hirayae, K.; Hibi, T.; Akutsu, K. Synergistic antifungal activity of chitinolytic enzymes and prodigiosin produced by biocontrol bacterium, Serratia marcescens strain B2 against gray mold pathogen, Botrytis cinerea.J. Gen. Plant Pathol. 2001, 67, 312-317, https://doi.org/10.1007/PL00013038.

135. Suryanto, D.; Wahyuni, S.; Siregar, E.B.M.; Munir, E. Utilization of chitinolytic bacterial isolates to control anthracnose of cocoa leaf caused by Colletotrichum gloeosporioides. Afr. J. Biotechnol. 2014, 13, 16311637, https://doi.org/10.5897/AJB11.3687.

136. Sindhu, S.S.; Dadarwal, K.R. Chitinolytic and cellulolytic Pseudomonas sp. antagonistic to fungal pathogens enhances nodulation by Mesorhizobium sp. in Cicer chickpea. Microbiol. Res. 2001, 156, 353358, https://doi.org/10.1078/0944-5013-00120.

137. Carozzi, N.B.; Koziel, M. Chitinase for insect control. In: Advances in insect control: the role of transgenic plants, Carozzi, N.B., Koziel, M., Eds., Taylor \& Francis, 2005, pp. 211-220, https://doi.org/10.1002/(SICI)1526-4998(200003)56:3<294::AID-PS100>3.0.CO;2-8.

138. Yadav, M.; Goswami, P.; Paritosh, K.; Kumar, M.; Pareek, N.; Vivekanand, V. Seafood waste: A source for preparation of commercially employable chitin/chitosan materials. Biores. Bioproc. 2019, 6, 8, https://doi.org/10.1186s40643-019-0243-y.

139. Casadidio, C.; Peregrina, D.V.; Gigliobianco, M.R.; Deng, S.; Censi, R.; Di Martino, P. Chitin and chitosans: Characteristics, eco-friendly processes, and applications in cosmetic science. Mar. Drugs 2019, 17, 369, https://doi.org/10.3390/md17060369.

140. Liu, C.; Wu, K.; Wu, Y.; Gao, Y.; Nig, C. Reduction of Bacillus thuringiensis Cry1Ac toxicity against Helicoverpa armigera by a soluble toxin-binding cadherin fragment. J. Insect. Physiol. 2009, 55, 686-693, https://doi.org/10.1016/j.jinsphys.2009.05.001.

141. Rishad, K.S.; Rebello, S.; Shabanamol, P.S. Biocontrol potential of halotolerant bacterial chitinase from high yielding novel Bacillus pumilus MCB-7 autochthonous to mangrove ecosystem. Pest. Biochem. Physiol. 2016, 137, 36-41, https://doi.org/10.1016/j.pestbp.2016.09.005.

142. Rana Khalid, I.; Farhana Naureen, A. Chitinases Potential as bio-control. Biomed. J. Sci.Tech. Res. 2019, 14, 10994-11001, https://doi.org/10.26717/BJSTR.2019.14.002629

143. Singh, A.K.; Singh, A.; Joshi, P.; Combined application of chitinolytic bacterium Paenibacillus sp. D1 with low doses of chemical pesticides for better control of Helicoverpa armigera. Int. J. Pest Manage. 2016, 62, 222-227, https://doi.org/10.1080/09670874.2016.1167267.

144. Zhong, W.; Ding, S.; Guo, H. The chitinase C gene PsChiC from Pseudomonas sp. and its synergistic effects on larvicidal activity. Genet. Mol. Biol. 2015, 38, 366-372, https://doi.org/10.1590/S1415475738320140320.

145. Sasaki, C.; Varum, K.M.; Itoh, Y.; Tamoi, M.; Fukamizo, T. Rice chitinases: Sugar recognition specificities of the individual subsites. Glycobiol. 2006, 16, 1242-1250, https://doi.org/10.1093/glycob/cwl043.

146. Yong, S.K.; Shrivastava, M.; Srivastava, P.; Kunhikrishnan, A.; Bolan, N. Environmental applications of chitosan and its derivatives. In: Reviews of environmental contamination and toxicology. Springer Int. Publ. 2015, 233, 1-43, https://doi.org/10.1007/978-3-319-10479-9_1.

147. Elanchezhiyan, S.S.; Meenakshi, S. Facile synthesis of metal incorporated chitin for the recovery of oil from oil-in-water emulsion using adsorptive method. J. Cleaner Prod. 2016, 139, 1339-1350, https://doi.org/10.1.16.j.jclepro.2016.08.119.

148. Beier, S.; Bertilsson, S. Bacterial chitin degradation: Mechanisms and ecophysiological strategies. Front. Microbiol. 2013, 4, 149, https://doi.org/10.3389/fmicb.2013.00149.

149. Yoshizuka, K.; Lou, Z.; Inoue, K. Silver-complexed chitosan microparticles for pesticide removal. React. Funct. Polym. 2000, 44, 47-54, https://doi.org/10.1016/S1381-5148(99)00076-0.

150. Prado, A.G.; Torres, J.D.; Faria, E.A.; Dias, S.C. Comparative adsorption studies of indigo carmine dye on chitin and chitosan. J. Colloid Interf. Sci. 2004, 277, 43-47, https://doi.org/10.1016/j.jcis.2004.04.056.

151. Tang, H.; Zhou, W.; Zhang, L. Adsorption isotherms and kinetics studies of malachite green on chitin hydrogels. J. Hazard. Mater. 2012, 209, 218-225, https://doi.org/10.1016/j.jhazmat.2012.01.010.

152. Saravanan, D.; Gomathi, T.; Sudha, P.N. Sorption studies on heavy metal removal using chitin/bentonite biocomposite. Int. J. Biol. Macromol. 2013, 53, 67-71, https://doi.org/10.1016/j.ijbiomac.2012.11.005.

153. Soni, U.; Bajpai, J.; Singh, S.K.; Bajpai, A.K. Evaluation of chitosan-carbon based biocomposite for 
efficient removal of phenols from aqueous solutions. J. Water Process Engin. 2017, 16, 56-63, https://doi.org/10.1016/j.jwpe.2016.12.004.

154. Dolphen, R.; Sakkayawong, N.; Thiravetyan, P.; Nakbanpote, W. Adsorption of reactive red 141 from wastewater on to modified chitin. J. Hazard. Mater. 2007, 145, 250255, https://doi.org/10.1016/j.jhazmat.2006.11.026.

155. Gandhi, M.R.; Kousalya, G.N.; Meenakshi, S. Removal of copper (II) using chitin/chitosan nanohydroxyapatite composite. Int. J. Biol. Macro Mol. 2010, 48, 119-124, https://doi.org/10.1016/j.ijbiomac.2010.10.009.

156. Dolphen, R.; Thiravetyan, P. Adsorption of melanoidins by chitin nanofibers. Chem. Eng. J. 2011, 166, 890-895, https://doi.org/10.1016/j.cej.2010.11.063.

157. Govindsamy, V.; Gunaratna, K.R.; Balasubramanian, R. Properties of extracellular chitinase from Myrothecium verrucaria, an antagonist to the groundnut rust Puccinia arachidis. Can. J. Plant Pathol. 1998, 20, 62-68, https://doi.org/10.1007/BF00414876.

158. Giambattista, R.D.; Federici, F.; Petruccioli, M.; Fence, M. The chitinolytic activity of Penicillium janthinellum P9: Purification, partial characterization and potential application. J. Appl. Microbiol. 2001, 91, 498-505, https://doi.org/10.1046/j.1365-2672.2001.01409.x. 